\title{
Nitrogen fixation in the East China Sea and southern Yellow Sea during summer 2006
}

\author{
Run Zhang ${ }^{1}$, Min Chen ${ }^{1,2, *}$, Jianping Cao ${ }^{1}$, Qiang Ma ${ }^{1}$, Junhong Yang ${ }^{1}$, \\ Yusheng Qiu ${ }^{1,2}$
}

${ }^{1}$ Department of Oceanography, and ${ }^{2}$ State Key Laboratory of Marine Environmental Science, Xiamen University, Xiamen, 361005, PR China

\begin{abstract}
Nitrogen fixation in the subtropical East China Sea (ECS) and the southern Yellow Sea (YS) were measured using ${ }^{15} \mathrm{~N}_{2}$ tracer assay during June and July 2006. Depth-integrated nitrogen fixation (2 to $221 \mu \mathrm{mol} \mathrm{N} \mathrm{m}{ }^{-2} \mathrm{~d}^{-1}$ ) was highest in the oceanic main path of the Kuroshio Current in the northeastern ECS, and in the mesohaline (surface salinity 30 to 34 ) stations. Very little $\mathrm{N}_{2}$ fixation was encountered in the low-salinity (surface salinity $<30$ ) area, and we suggest that $\mathrm{N}_{2}$ fixation was hindered by the nutrient conditions (lack of 'excess' phosphate relative to nitrate, $\mathrm{xsPO}_{4}=\left[\mathrm{PO}_{4}\right]-\left[\mathrm{NO}_{3}\right] / 16$ ) near the Changjiang (Yangtze River) mouth. In the mesohaline waters, $\mathrm{N}_{2}$ fixation was positively correlated with the vertical density $\left(\sigma_{t}\right)$ gradient in the upper water column $(30 \mathrm{~m})$, indicating that $\mathrm{N}_{2}$ fixation can also be controlled by physical regime, and enhanced water column stratification may promote $\mathrm{N}_{2}$ fixation during summer. $\mathrm{N}_{2}$ fixation met 0.01 to $4.6 \%$ of nitrogen demand by primary production, suggesting that $\mathrm{N}_{2}$ fixation was not a major contributor to primary production in the study area. Estimated new $\mathrm{N}$ flux by $\mathrm{N}_{2}$ fixation to the ECS continental shelf $(13 \mathrm{Gg} \mathrm{N})$ during summer is at the same order of magnitude as atmospheric deposition, but much lower than either the Kuroshio subsurface water upwelling or the Changjiang riverine input.
\end{abstract}

KEY WORDS: Nitrogen fixation - East China Sea $\cdot$ Southern Yellow Sea $\cdot{ }^{15} \mathrm{~N}_{2}$ assay Resale or republication not permitted without written consent of the publisher

\section{INTRODUCTION}

Marine pelagic $\mathrm{N}_{2}$ fixation is of great importance because it not only provides significant levels of combined nitrogen to the environment, but also regulates the sequestration of atmospheric $\mathrm{CO}_{2}$ to a large extent (Karl et al. 2002). Recent studies suggest that $\mathrm{N}_{2}$ fixation may be much more widespread in marine environments than previously thought, thus its importance in nitrogen biogeochemical cycles may have been underestimated, especially in the tropical and subtropical marginal sea areas (Voss et al. 2006, Subramaniam et al. 2008, Riemann et al. 2010).

The subtropical East China Sea (ECS) is the largest marginal sea in the western Pacific with a broad continental shelf. The ECS and the adjacent Yellow Sea (YS) are bounded by the Chinese mainland to the west, the Kuroshio on the slope side, and the Korean Peninsula to the northeast (see Fig. 1). The Kuroshio, the Changjiang (Yangtze River) runoff, and the East Asia monsoons are the dominant factors affecting the circulation in the ECS (Liu et al. 2003). The Kuroshio, a strong western boundary current of the Pacific Ocean (the northeasterly flowing continuation of the Pacific North Equatorial Current) with a width of about $100 \mathrm{~km}$, flows northeastward approximately along the $200 \mathrm{~m}$ isobath into the ECS and plays a key role in the current system and nutrient budget for the ECS continental shelf (Chen et al. 1995, Chen et al. 1999, Lee \& Matsuno 2007). To the west, the Changjiang, the third largest river in terms of freshwater discharge in the world, empties large nutrient loads into the shelf waters in wet seasons (Tian et al. 1993, Zhang 1996, Ichikawa \& Beardsley 2002). In summer, 
the southwest monsoon may extend the plume area affected by the Changjiang Diluted Water (CDW).

$\mathrm{N}_{2}$ fixation in the ECS and the YS, 2 marginal seas bordering the western Pacific, has rarely been studied, especially for directly measured rates. Previous studies have shown that Trichodesmium spp. is relatively abundant in the Kuroshio water and the adjacent ECS continental shelf water (Nagasawa \& Marumo 1967, Marumo \& Asaoka 1974, Marumo \& Nagasawa 1976, Saino 1977, Minagawa \& Wada 1986, Chang et al. 2000, Suzuki et al. 2007, Shiozaki et al. 2010). On the ECS shelf and the bordering YS, Trichodesmium has been found almost all year round and occasionally forms blooms (Zhou 1962, Chen 1982, Yang 1998, Chang et al. 2000, Wang 2002, Yan et al. 2002, Bai et al. 2007, Ding 2009). The diatomsymbiotic cyanobacteria Richelia intracellularis are also present in the Kuroshio-influenced ECS (Ding 2009, Shiozaki et al. 2010). Stable nitrogen isotope $\left({ }^{15} \mathrm{~N}\right)$ evidence from either the blooming organisms (Minagawa \& Wada 1986) or nitrate (Liu et al. 1996) indicate $\mathrm{N}_{2}$ fixation in the ECS.

Unfortunately, directly measured rates of $\mathrm{N}_{2}$ fixation in the ECS are sparse and confined to part of the Kuroshio water in the vicinity of the Japanese islands (Saino 1977, Shiozaki et al. 2010). To our knowledge, no $\mathrm{N}_{2}$ fixation rates have been reported for the YS. To improve basic understanding of the biogeochemical cycle in the marginal seas, it is important to measure $\mathrm{N}_{2}$ fixation in the ECS and the YS. In this study, we measure $\mathrm{N}_{2}$ fixation and consider some possible physico-chemical controlling factors in the ECS and the YS during summer. In addition, the importance of new nitrogen provided by $\mathrm{N}_{2}$ fixation in supporting local primary production and the nitrogen budgets on the continental shelf during summer will be evaluated.

\section{MATERIALS AND METHODS}

\section{Sampling}

A total of 18 stations were occupied along 5 transects in the ECS and the southern YS (25 to $35^{\circ} \mathrm{N}$ ) from 28 June to 15 July (southwest monsoon season) 2006 on board RV 'Dongfanghong 2 '. The southernmost station S1010 (1769 m) is located in the Kuroshio main path, northeast of Taiwan, while the northernmost $\left(35^{\circ} \mathrm{N}\right)$ transect S03 is located in the southern YS, and the remaining stations are located on the shallow shelf with a depth less than $100 \mathrm{~m}$ in the ECS (Fig. 1). Seawater samples were generally collected from standard depths (mainly from 1, 10, 30, 50, and $75 \mathrm{~m}$ ) at 14 stations, using Go-Flo bottles mounted on a CTD rosette. At Stn S1010, seawater was only sampled for the upper $50 \mathrm{~m}$ due to the sampling constraints, which may lead to an underestimated depth-integrated rate. At Stns S0402, S0404, FJ07, and S0504, only surface water (about $1 \mathrm{~m}$ ) was sampled. Note that at Stn S1006, primary production was sampled only at the surface. Nutrient concentrations were not measured at Stn FJ07.

\section{Incubation experiments}

$\mathrm{N}_{2}$ fixation was measured using the ${ }^{15} \mathrm{~N}_{2}$ tracer assay (Montoya et al. 1996). In brief, duplicate sam-

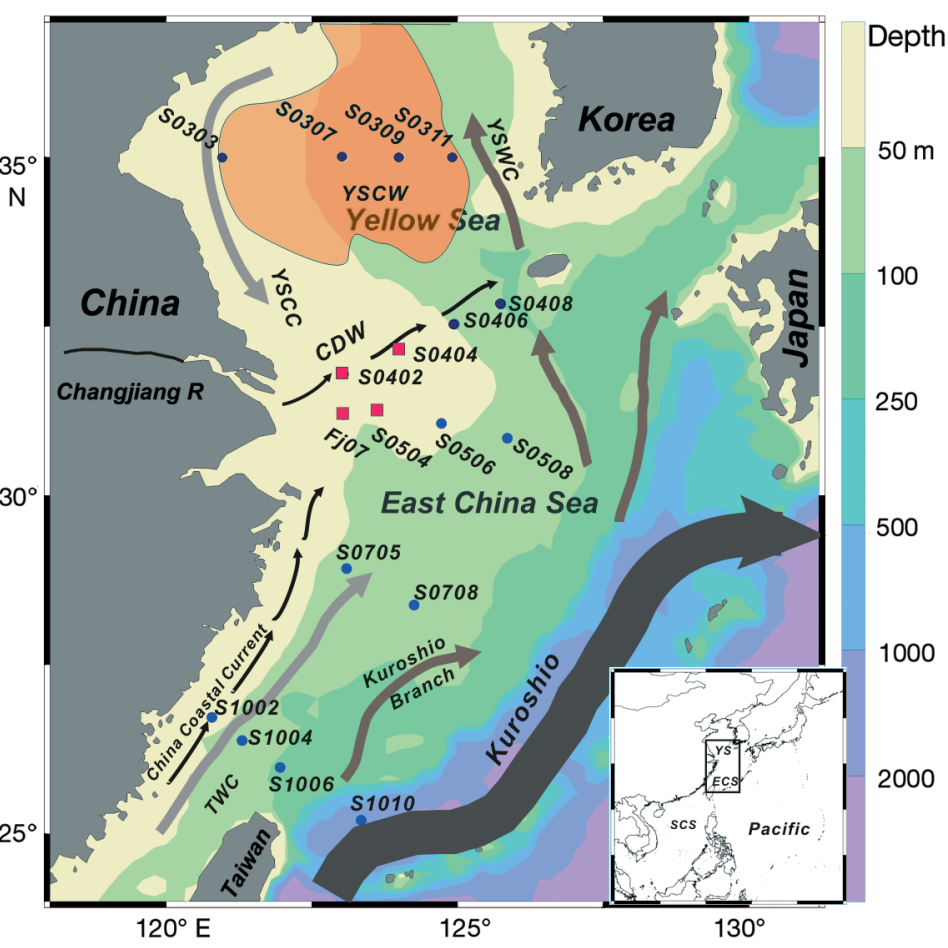

Fig. 1. Sampling locations $(n=18)$ in the East China Sea (ECS) and the southern Yellow Sea (YS) during summer 2006. The symbols indicate the stations that were either ( $\bullet$ ) vertically sampled or (匹) only surface-sampled. The arrows represent the schematic major currents in summer: Kuroshio, the Kuroshio branch, the Taiwan Warm Current (TWC), the China Coastal Current, the Changjiang Diluted Water (CDW), the Yellow Sea Coastal Current (YSCC) and the Yellow Sea Warm Current (YSWC). The locations of the currents are taken from Guan (1994). The orange shaded area in the Yellow Sea represents the approximate maximum extent of the Yellow Sea Cold Water (YSCW) during summer (Weng et al. 1989) 
ples were filled bubble-free into $600 \mathrm{ml}$ transparent glass bottles and sealed, then spiked with $1.0 \mathrm{ml}$ ${ }^{15} \mathrm{~N}_{2}\left(99\right.$ atom\% $\left.{ }^{15} \mathrm{~N}\right)$ via a septum using a gastight syringe (VICI, $1 \mathrm{ml}$ ), with the pressure across the septum balanced by another syringe. The bottles were gently shaken for several minutes before incubation. Primary production was measured using the ${ }^{14} \mathrm{C}$ method (Wolfe \& Schelske 1967). Water samples were immediately transferred into three $125 \mathrm{ml}$ glass bottles, two assigned as light bottles and one as dark, and $0.8 \mu \mathrm{Ci} \mathrm{NaH}^{14} \mathrm{CO}_{3}$ was added to each bottle. All of the bottles for $\mathrm{N}_{2}$ fixation and primary production measurements were fitted with appropriate screens to simulate the light densities (Table 1) and incubated on deck in flowing surface water. After $24 \mathrm{~h}$ incubation, $\mathrm{N}_{2}$ fixation and primary production samples were gently $(<100 \mathrm{~mm} \mathrm{Hg})$ filtered onto precombusted $\left(450^{\circ} \mathrm{C}, 4 \mathrm{~h}\right)$ Whatman $\mathrm{GF} / \mathrm{F}$ filters or mixed cellulose ester membranes $(0.2 \mu \mathrm{m})$, respectively, before being stored frozen. Natural ${ }^{15} \mathrm{~N}$ abundance in suspended particulate organic matter was measured for calculating the ${ }^{15} \mathrm{~N}$ enrichment during incubation.

\section{Analyses}

On return to the land laboratory, filters for particulate organic nitrogen (PON) and ${ }^{15} \mathrm{~N}$ measurements were dried at $60^{\circ} \mathrm{C}$ and pelletized in tin capsules.
PON and its nitrogen isotopic abundance were measured using an elemental analyzer (Carlo Erba NC 2500) coupled to a Finnigan MAT Delta ${ }^{\text {plus }}$ XP isotope ratio mass spectrometer. Reproducibility of nitrogen isotope analysis (in the convention of $\delta$ notation) was within $0.2 \%$. The volumetric $\mathrm{N}_{2}$ fixation rate $(N F$, $\mathrm{nmol} \mathrm{N} \mathrm{m}{ }^{-3} \mathrm{~h}^{-1}$ ) was calculated following Montoya et al. (1996):

$N F\left(n m o l ~ \mathrm{~N} \mathrm{~m}^{-3} \mathrm{~h}^{-1}\right)=\frac{1}{\Delta \mathrm{t}}\left(\frac{A_{\mathrm{PN}_{\mathrm{f}}}-A_{\mathrm{PN}_{0}}}{A_{\mathrm{N}_{2}}-A_{\mathrm{PN}_{0}}}\right) \frac{\mathrm{PON}_{0}+\mathrm{PON}_{\mathrm{f}}}{2}$

where $\Delta t$ is the incubation time, PON is the concentration of particulate organic nitrogen, and $A_{\mathrm{PN}_{\mathrm{f}^{\prime}}} A_{\mathrm{PN}_{0}}$ and $A_{\mathrm{N}_{2}}$ are absolute abundance ratios of final and natural $(t=0)$ particulate organic nitrogen and the $\mathrm{N}_{2}$ substrate in the incubation bottle (originally dissolved plus manually injected), respectively.

Inorganic carbon on the primary production sample filters was removed by acid fuming. The assimilated ${ }^{14} \mathrm{C}$ radioactivity was measured on a liquid scintillation counter (Perkin-Elmer TriCarb 2900TR). Primary production $(P P)$ was calculated as:

$$
P P\left(\mathrm{mmol} \mathrm{C} \mathrm{m}^{-3} \mathrm{~h}^{-1}\right)=\frac{\left(R_{\mathrm{S}}-R_{\mathrm{B}}\right) \cdot \mathrm{TCO}_{2}}{R \cdot \Delta t}
$$

where $R_{\mathrm{S}}$ and $R_{\mathrm{B}}$ are the radioactivities of ${ }^{14} \mathrm{C}(\mu \mathrm{Ci})$ in light and dark bottles after correction for quenching, respectively, $R$ is the added radioactivity of $\mathrm{NaH}^{14} \mathrm{CO}_{3}(0.8 \mu \mathrm{Ci})$, and $\mathrm{TCO}_{2}$ is the total carbon dioxide $\left(\mathrm{mmol} \mathrm{C} \mathrm{m}^{-3}\right)$ in seawater.

Table 1. Sampling date, longitude, latitude, bottom depth, and light intensity setting

\begin{tabular}{|c|c|c|c|c|c|}
\hline Station & $\begin{array}{c}\text { Date } \\
(\mathrm{mo} / \mathrm{d} / \mathrm{yr})\end{array}$ & $\begin{array}{c}\text { Longitude } \\
\left({ }^{\circ} \mathrm{E}\right)\end{array}$ & $\begin{array}{c}\text { Latitude } \\
\left({ }^{\circ} \mathrm{N}\right)\end{array}$ & $\begin{array}{l}\text { Bottom } \\
\text { (m) }\end{array}$ & Sampling layer (irradiance level setting, \%) \\
\hline S0303 & $7 / 15 / 2006$ & 121.00 & 35.00 & 37 & $1 \mathrm{~m} \mathrm{(100),} 10 \mathrm{~m}(50), 33 \mathrm{~m}(0.1)$ \\
\hline S0307 & $7 / 14 / 2006$ & 123.03 & 35.00 & 78 & $1 \mathrm{~m} \mathrm{(100),} 10 \mathrm{~m}(50), 30 \mathrm{~m} \mathrm{(10),}, 50 \mathrm{~m}(0.1)$ \\
\hline S0309 & $7 / 14 / 2006$ & 124.01 & 35.01 & 82 & $1 \mathrm{~m} \mathrm{(100),} 10 \mathrm{~m} \mathrm{(50),} 30 \mathrm{~m}(10), 60 \mathrm{~m}(0.1)$ \\
\hline S0311 & $7 / 14 / 2006$ & 124.91 & 35.01 & 88 & $1 \mathrm{~m} \mathrm{(100),}, 10 \mathrm{~m}(50), 30 \mathrm{~m} \mathrm{(10),} 75 \mathrm{~m}(0.1)$ \\
\hline S0402 & $7 / 10 / 2006$ & 123.04 & 31.80 & 43 & $1 \mathrm{~m}(100)$ \\
\hline S0404 & $7 / 11 / 2006$ & 123.99 & 32.16 & 44 & $1 \mathrm{~m} \mathrm{(100)}$ \\
\hline S0406 & $7 / 11 / 2006$ & 124.94 & 32.53 & 59 & $1 \mathrm{~m}(100), 10 \mathrm{~m}(50), 20 \mathrm{~m}(10), 30 \mathrm{~m}(0.1)$ \\
\hline S0408 & $7 / 11 / 2006$ & 125.74 & 32.83 & 94 & $1 \mathrm{~m} \mathrm{(100),} 10 \mathrm{~m} \mathrm{(50),} 30 \mathrm{~m}(10), 75 \mathrm{~m}(0.1)$ \\
\hline FJ07 & $7 / 7 / 2006$ & 123.04 & 31.20 & 66 & $1 \mathrm{~m} \mathrm{(100)}$ \\
\hline S0504 & $7 / 7 / 2006$ & 123.63 & 31.26 & 108 & $1 \mathrm{~m} \mathrm{(100)}$ \\
\hline S0506 & $7 / 7 / 2006$ & 124.72 & 31.06 & 51 & $1 \mathrm{~m}(100), 10 \mathrm{~m} \mathrm{(50),} 30 \mathrm{~m}(10), 48 \mathrm{~m}(0.1)$ \\
\hline S0508 & $7 / 12 / 2006$ & 125.85 & 30.85 & 75 & $1 \mathrm{~m}(100), 10 \mathrm{~m} \mathrm{(50),} 30 \mathrm{~m}(10), 50 \mathrm{~m}(1), 65 \mathrm{~m}(0.1)$ \\
\hline S0705 & $7 / 4 / 2006$ & 123.09 & 28.92 & 70 & $1 \mathrm{~m} \mathrm{(100),} 10 \mathrm{~m}(50), 30 \mathrm{~m} \mathrm{(10),} 50 \mathrm{~m}(0.1)$ \\
\hline S0708 & $7 / 4 / 2006$ & 124.26 & 28.38 & 96 & $1 \mathrm{~m}(100), 10 \mathrm{~m} \mathrm{(50),}, 30 \mathrm{~m}(30), 50 \mathrm{~m} \mathrm{(10),} 75 \mathrm{~m} \mathrm{(0.1)}$ \\
\hline S1002 & $6 / 28 / 2006$ & 120.79 & 26.72 & 50 & 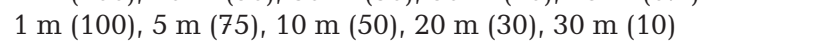 \\
\hline S1004 & $6 / 28 / 2006$ & 121.30 & 26.38 & 79 & $1 \mathrm{~m}(100), 10 \mathrm{~m}(40), 20 \mathrm{~m}(30), 30 \mathrm{~m}(10), 50 \mathrm{~m}(1), 78 \mathrm{~m}(0.1)$ \\
\hline $\mathrm{S} 1006^{\mathrm{a}}$ & $6 / 30 / 2006$ & 121.95 & 25.98 & 104 & 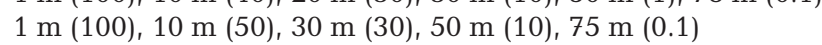 \\
\hline S1010 & $7 / 1 / 2006$ & 123.35 & 25.20 & 1769 & $1 \mathrm{~m} \mathrm{(100),} 10 \mathrm{~m} \mathrm{(50),} 30 \mathrm{~m} \mathrm{(30),}, 50 \mathrm{~m} \mathrm{(10)}$ \\
\hline
\end{tabular}


The depth-integrated $\mathrm{N}_{2}$ fixation rate ( $\mu \mathrm{mol}$ $\mathrm{N} \mathrm{m}^{-2} \mathrm{~d}^{-1}$ ) and primary production (mmol $\mathrm{C} \mathrm{m}^{-2}$ $\mathrm{d}^{-1}$ ) were estimated by trapezoidal integration over the sampling depths. Temperature, salinity and density were recorded by Sea Bird 911 Plus CTD sensors during the cast. Nitrate was determined by the standard pink azo dye method, while phosphate and silicate were determined by the standard molybdenum blue method onboard, immediately after sampling. All the methods and procedures were in accordance with those recommended by Hansen \& Koroleff (1999). The precisions for determining nitrate, phosphate and silicate were \pm 0.1 , \pm 0.02 and $\pm 0.2 \mu \mathrm{M}$, respectively.

\section{RESULTS}

\section{Hydrographic conditions}

The surface distributions of salinity (SSS, 27.4 to 34.3), temperature (SST, 21.4 to $\left.29.6^{\circ} \mathrm{C}\right)$, nitrate (0 to $14.9 \mu \mathrm{M})$, phosphate ( 0 to $0.13 \mu \mathrm{M})$ and silicate ( 0 to 18.6 $\mu \mathrm{M}$ for $\mathrm{SiO}_{3}{ }^{2-}$ ) in the study area are shown in Fig. 2. The intrusion of the Kuroshio water onto the ECS continental shelf was evidenced by the SSS tongues in the southeastern part of the study area, because high salinity surface waters in the ECS originate mainly from the Kuroshio (Chen et al. 1995), while the less saline northward flow of Taiwan Warm Current water and the large freshwater discharge from the Changjiang result in low salinities in coastal areas (Beardsley et al. 1985). We thus classified our sampling stations into 3 categories according to their SSS: the low-salinity group with SSS <30 ( $\mathrm{n}=6)$, which is found approximately along the boundary of the Changjiang river plume (Gong et al. 1996), the mesohaline group with SSS between 30 and 34 ( $\mathrm{n}=11$ ) and the oceanic Kuroshio mainstream in the northeastern ECS (Stn S1010).

Surface nitrate and silicate distributions generally mirrored the distribution of SSS. Mean values of surface nitrate $(6.4 \mu \mathrm{M}, 0.6$ to $14.9 \mu \mathrm{M}, \mathrm{n}=5)$ and silicate $(12.5 \mu \mathrm{M}, 4.6$ to $18.6 \mu \mathrm{M}, \mathrm{n}=5)$ in the lowsalinity waters are the highest among the subregions, while surface nitrate $(0.3 \mu \mathrm{M}, 0$ to $1.4 \mu \mathrm{M}$, $\mathrm{n}=11$ ) decreased below the detection limit at 7 of 11 stations in the mesohaline waters or the Kuroshio. Surface silicate $(3.1 \mu \mathrm{M}, 0$ to $13.5 \mu \mathrm{M}, \mathrm{n}=11)$ also decreased dramatically in the mesohaline waters. In contrast, the differences in surface phosphate concentrations among the 3 sub-regions were smaller (Table 2).

\section{$\mathbf{N}_{2}$ fixation}

The surface $\mathrm{N}_{2}$ fixation rate ( $\mathrm{nmol} \mathrm{N} \mathrm{m}^{-3} \mathrm{~h}^{-1}$ ) was very low for the low-salinity stations $(4.2 \pm 5.6 \mathrm{nmol}$ $\mathrm{N} \mathrm{m}^{-3} \mathrm{~h}^{-1}$ ), and became much more active at the mesohaline stations $\left(38.3 \pm 48.3 \mathrm{nmol} \mathrm{N} \mathrm{m}^{-3} \mathrm{~h}-1\right)$ (Fig. 3). The Kuroshio station had the highest surface $\mathrm{N}_{2}$ fixation rate (193 $\mathrm{nmol} \mathrm{N} \mathrm{m}^{-3} \mathrm{~h}^{-1}$ ) among all stations. It is interesting to see that the southern YS was characterized by a higher surface $\mathrm{N}_{2}$ fixation rate compared to the ECS continental shelf (72 versus $12 \mathrm{nmol} \mathrm{N} \mathrm{m}^{-3} \mathrm{~h}^{-1}$ ). Depth profiles showed that $\mathrm{N}_{2}$ fixation rates appeared higher at the surface or subsurface (10 to $20 \mathrm{~m}$ ), and showed less strong variation than those for primary production (Fig. 4). It is interesting to note that even higher $\mathrm{N}_{2}$ fixation rates occurred at the near-bottom layers of Stns S0303 and S0307. Although the exact cause for such an 'anomaly' is still unknown, there are 2 possible reasons. First, there are unicellular diazotrophs that actively fix $\mathrm{N}_{2}$ at relatively low light levels (Montoya et al. 2004, Church et al. 2009). Second, there may be benthic $\mathrm{N}_{2}$ fixers present. This has been shown for the Sanya Bay of the northern South China Sea, where benthic cyanobacteria can fix $\mathrm{N}_{2}$ at a high rate during summer (Dong et al. 2008). However, this will not be discussed further because we do not have direct data to test these possibilities.

Depth-integrated $\mathrm{N}_{2}$ fixation rates ranged between 2 and $221 \mu \mathrm{mol} \mathrm{N} \mathrm{m} \mathrm{N}^{-2} \mathrm{~d}^{-1}$ in the whole area (Fig. 5A). The mean depth-integrated $\mathrm{N}_{2}$ fixation rate of lowsalinity stations $\left(7 \pm 6 \mu \mathrm{mol} \mathrm{N} \mathrm{m}^{-2} \mathrm{~d}^{-1}, \mathrm{n}=2\right)$ was much lower than that of the mesohaline stations (53 \pm $47 \mu \mathrm{mol} \mathrm{N} \mathrm{m} \mathrm{N}^{-1}, \mathrm{n}=11$ ) or the Kuroshio station (221 $\mu \mathrm{mol} \mathrm{N} \mathrm{m}^{-2} \mathrm{~d}^{-1}$ ). We also found that depth-integrated $\mathrm{N}_{2}$ fixation rate along $35^{\circ} \mathrm{N}$ was much higher than that of the ECS continental shelf.

\section{Primary production}

The primary production rate decreased with depth at all stations, and much higher rates were observed at Stns S0508 and S0705 (Fig. 4). The depth-integrated primary production (mmol $\mathrm{C} \mathrm{m}^{-2} \mathrm{~d}^{-1}$ ) was 489 at Stn S0508 and 534 at Stn S0705 (Fig. 5B). Such values are much higher than those of either the remaining stations in this study, or the published mean rates of around $100 \mathrm{mmol} \mathrm{C} \mathrm{m} \mathrm{m}^{-2} \mathrm{~d}^{-1}$ on the ECS continental shelf during summer (Hama et al. 1997, Gong et al. 2003, Chen et al. 2004), indicating that these 2 stations were likely under phytoplankton bloom conditions. We suggest that the blooms at Stn S0508 may 
Fig. 2. Distributions of sea surface (A) salinity, (B) temperature, (C) nitrate, (D) phosphate, and (E) silicate in $\mu \mathrm{M}$ in the East China Sea and the southern Yellow Sea. Note that there are more hydrographic sampling stations ( $\mathrm{n}=64$ for salinity and temperature, $\mathrm{n}=21$ for nutrients) than in the incubation experiment. The additional hydrographic data were provided by the Program 'Marine Physical Variations in Eastern Marginal Seas of China and their Environmental Impacts' (www3.ouc.edu.cn/973/)
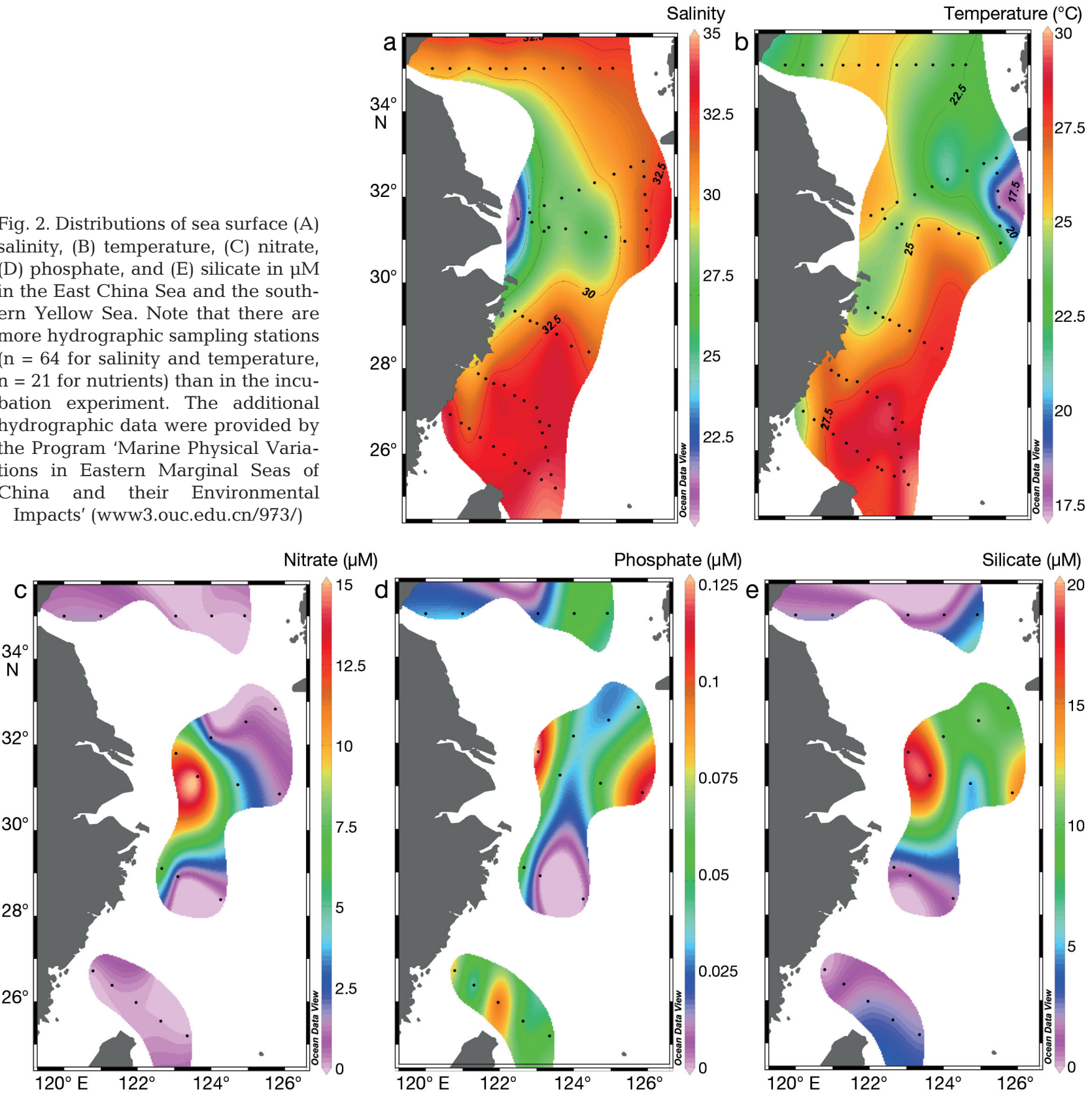

have been triggered by the intensified cold eddy (30 to $32^{\circ} \mathrm{N}, 124$ to $127^{\circ} \mathrm{E}$ ) in summer (Chen et al. 1994, Yuan \& Guan 2007). Similarly, Stn S0705 is located in the well-known Min-Zhe coastal upwelling region (caused by the southwest monsoon that prevails in summer acting together with the northward Taiwan Warm Current and China Coastal Current; Chen et al. 2004), which creates the most important fishing ground (Zhoushan fishing ground) in China. The Kuroshio was the least productive among all the stations, with a depth-integrated primary production of $32 \mathrm{mmol} \mathrm{C} \mathrm{m}^{-2} \mathrm{~d}^{-1}$. In addition, the mean depth- integrated primary production for the low-salinity stations $\left(121 \pm 16 \mathrm{mmol} \mathrm{C} \mathrm{m} \mathrm{C}^{-1}, \mathrm{n}=2\right)$ was close to that of the non-blooming mesohaline stations (136 \pm $28 \mathrm{mmol} \mathrm{C} \mathrm{m}^{-2} \mathrm{~d}^{-1}, \mathrm{n}=8$ ).

\section{DISCUSSION}

\section{Variations in $\mathbf{N}_{2}$ fixation}

Our results show that the low-salinity waters are a suitable environment for $\mathrm{N}_{2}$ fixation, and this is con- 
Table 2. Summary of means and standard deviations of variables in the 3 regions. $\mathrm{xsPO}_{4}$ : excess $\mathrm{PO}_{4}$; $\mathrm{ND}$ : not detected

\begin{tabular}{|c|c|c|c|c|c|c|c|c|c|}
\hline Region & $\begin{array}{c}\text { No. of } \\
\text { stations }\end{array}$ & Salinity & $\begin{array}{l}\text { Temperature } \\
\left({ }^{\circ} \mathrm{C}\right)\end{array}$ & $\begin{array}{l}\mathrm{NO}_{3}^{-} \\
(\mu \mathrm{M})\end{array}$ & $\begin{array}{c}\text { Surface } \\
\mathrm{SiO}_{3}^{2-} \\
(\mu \mathrm{M})\end{array}$ & $\begin{array}{l}\mathrm{PO}_{4}^{3-} \\
(\mu \mathrm{M})\end{array}$ & $\begin{array}{c}\mathrm{xsPO}_{4} \\
(\mu \mathrm{M})\end{array}$ & $\begin{array}{l}\mathrm{N}_{2} \text { fixation } \\
\text { rate (nmol } \\
\left.\mathrm{N} \mathrm{m}^{-3} \mathrm{~h}^{-1}\right)\end{array}$ & $\begin{array}{c}\text { Depth-integrated } \\
\mathrm{N}_{2} \text { fixation rate } \\
\left(\mu \mathrm{mol} \mathrm{N} \mathrm{m}^{-2} \mathrm{~d}^{-1}\right)\end{array}$ \\
\hline Low salinity & 6 & $\begin{array}{l}28.67 \\
\pm 0.99\end{array}$ & $\begin{array}{l}24.07 \\
\pm 1.44\end{array}$ & $\begin{aligned} & 6.4 \\
\pm & 6.2^{\mathrm{a}}\end{aligned}$ & $\begin{array}{c}12.5 \\
\pm 6.0^{\mathrm{a}}\end{array}$ & $\begin{array}{c}0.06 \\
\pm 0.04^{\mathrm{a}}\end{array}$ & $\begin{array}{c}-0.34 \\
\pm 0.37^{\mathrm{a}}\end{array}$ & $\begin{array}{c}4.2 \\
\pm 5.6\end{array}$ & $\begin{aligned} & 7.8 \\
\pm & 7.7^{\mathrm{b}}\end{aligned}$ \\
\hline Mesohaline & 11 & $\begin{array}{l}31.97 \\
\pm 0.89\end{array}$ & $\begin{array}{l}25.02 \\
\pm 2.50\end{array}$ & $\begin{array}{c}0.3 \\
\pm 0.5\end{array}$ & $\begin{array}{r}3.1 \\
\pm 4.1\end{array}$ & $\begin{array}{c}0.05 \\
\pm 0.04\end{array}$ & $\begin{array}{r}0.03 \\
\pm 0.05\end{array}$ & $\begin{array}{c}38.3 \\
\pm 43.3\end{array}$ & $\begin{array}{c}53.4 \\
\pm 43.0\end{array}$ \\
\hline $\begin{array}{l}\text { Oceanic } \\
{ }^{\mathrm{a}} \mathrm{n}=5 ;{ }^{\mathrm{b}} \mathrm{n}=2\end{array}$ & 1 & 34.29 & 29.58 & ND & 2.3 & 0.06 & 0.06 & 193.1 & 220.8 \\
\hline
\end{tabular}

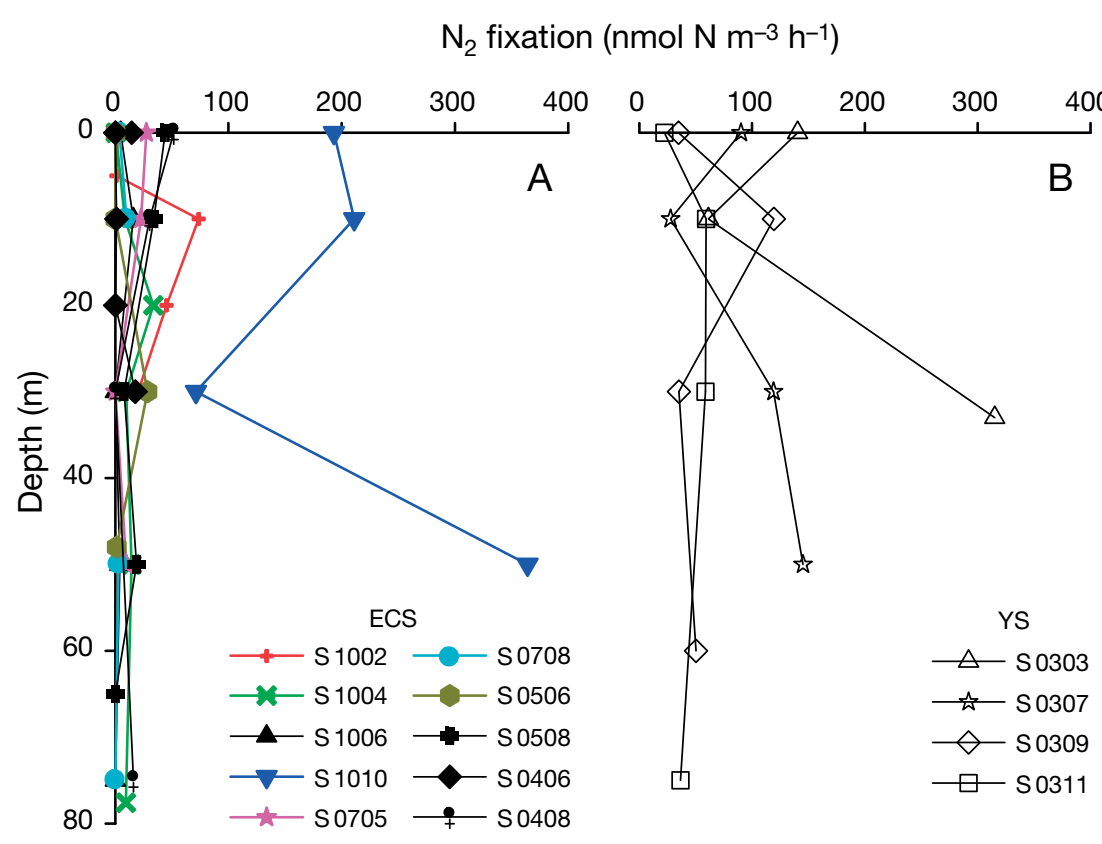

Fig. 3. Depth profiles of $N_{2}$ fixation rates in (A) the East China Sea (ECS) and (B) the southern Yellow Sea (YS). Note that only 2 profiles at Stns S0406 and S0506 fall within the low-salinity category tion rate of $232 \mu \mathrm{mol} \mathrm{N} \mathrm{m}^{-2} \mathrm{~d}^{-1}$ for the northeastern ECS Kuroshio mainstream during the summers of 2006 and 2007, which is very close to our result. Both results are higher than the $\mathrm{N}_{2}$ fixation rates previously measured via acetylene reduction assay of Trichodesmium (141 $\mu \mathrm{mol} \mathrm{N} \mathrm{m}^{-2} \mathrm{~d}^{-1}$, Saino \& Hattori 1980), or solely estimated from its abundance $\left(59 \mu \mathrm{mol} \mathrm{N} \mathrm{m}^{-2} \mathrm{~d}^{-1}\right.$, Chang et al. 2000).

For the first time, our direct results show that the southern YS, where the Yellow Sea Cold Water resides (and becomes most prominent in summer), is also a favorable environment for $\mathrm{N}_{2}$ fixation. This is partly consistent with published results showing that Trichodesmium can be observed all year round, and sometimes displays high abundance, dominating the phytoplankton species in the southern YS (Yang 1998, Bai et al. 2007). sistent with the reported Trichodesmium distribution in the Changjiang river plume in summer (Yang 1998), or in the tropical low-salinity waters near the Amazon River mouth (Subramaniam et al. 2008). Depth-integrated $\mathrm{N}_{2}$ fixation rates observed at the mesohaline stations generally fell in line with the published rates for subtropical sea areas, such as the Vietnamese upwelling region in the southern South China Sea (Voss et al. 2006, Grosse et al. 2010) and the North Pacific subtropical gyre (Karl et al. 1997, Church et al. 2009). A high $\mathrm{N}_{2}$ fixation rate at Stn $\mathrm{S} 1010$ was also consistent with the few available published results for the Kuroshio and adjacent waters. Shiozaki et al. (2010) reported an average ${ }^{15} \mathrm{~N}_{2}$ assay-based $\mathrm{N}_{2}$ fixa-

\section{Impact of nutrient conditions and water stratification on $\mathrm{N}_{2}$ fixation}

We suggest that the absence of $\mathrm{N}_{2}$ fixation in the low-salinity waters may largely arise from the nutrient conditions (Table 2). The Changjiang runoff contains very high concentrations of nitrate $(33 \mu \mathrm{M})$ and silicate $(100 \mu \mathrm{M})$ but relatively low phosphate (0.59 $\mu \mathrm{M}$, Zhang 1996); however, non- $\mathrm{N}_{2}$-fixing phytoplankton in the ECS consume $\mathrm{N}$ and $\mathrm{P}$ with a Redfield ratio of 16, in common with other areas in the world oceans (Chen et al. 1996, Wang et al. 2003), thus non- $\mathrm{N}_{2}$-fixing phytoplankton should have more than enough nitrate to fully consume all 
available phosphate (P-limiting) in the ECS lowsalinity waters (Wong et al. 1998, Wang et al. 2003). It is unlikely that $\mathrm{N}_{2}$ fixers will have an advantage over the fast-growing non- $\mathrm{N}_{2}$-fixing phytoplankton

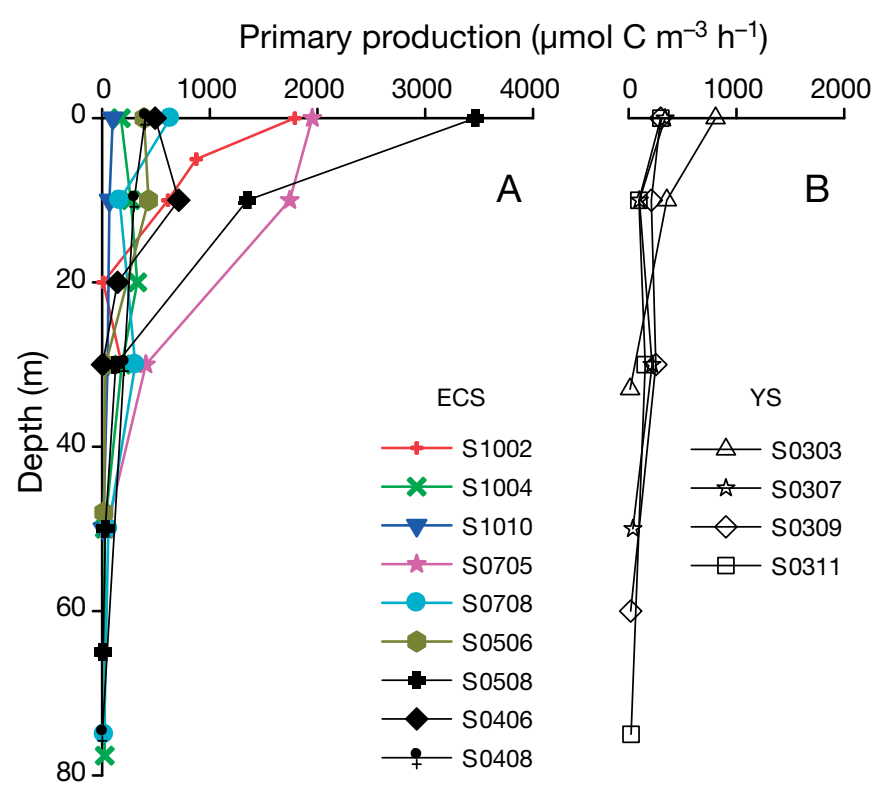

Fig. 4. Depth profiles of primary production in (A) the East China Sea (ECS) and (B) the southern Yellow Sea (YS) (dominated by a high abundance of the diatoms Chaetoceros and Rhizosolenia during summer, Luo et al. 2007) under such P-deficient nutrient conditions (Sañudo-Wilhelmy et al. 2001, Mills et al. 2004). With more mixing of coastal water with the oceanic water, the relative deficiency of phosphate was alleviated in the surface water of the mesohaline stations, as indicated by the 'excess' phosphate (expressed as $\mathrm{xsPO}_{4}=\left(\left[\mathrm{PO}_{4}{ }^{3-}\right]-\left[\mathrm{NO}_{3}{ }^{-}\right] / 16\right)$ under Redfield assumptions, Deutsch et al. 2007), and nutrient conditions turn more favorable for potential $\mathrm{N}_{2}$ fixation (Table 2).

Analysis of the physical regime suggests that $\mathrm{N}_{2}$ fixation in the mesohaline waters may have also been influenced by the degree of stratification in the upper water column, and $\mathrm{N}_{2}$ fixation can be promoted by enhanced stratification. This idea is supported by a positive correlation between $\mathrm{N}_{2}$ fixation and the vertical density $\left(\sigma_{t}\right)$ gradients in the upper $30 \mathrm{~m}$ of the mesohaline waters $\left(y=-12.3+590 x, \mathrm{r}^{2}\right.$ $=0.54, \mathrm{p}=0.01$; Fig. 6 ). It is consistent with the previous finding that Trichodesmium blooms on the ECS continental shelf and the YS mostly occur in summer, when the water column is highly stratified by riverine freshwater input and solar heating on the ECS continental shelf (Zhou 1962, Marumo \&
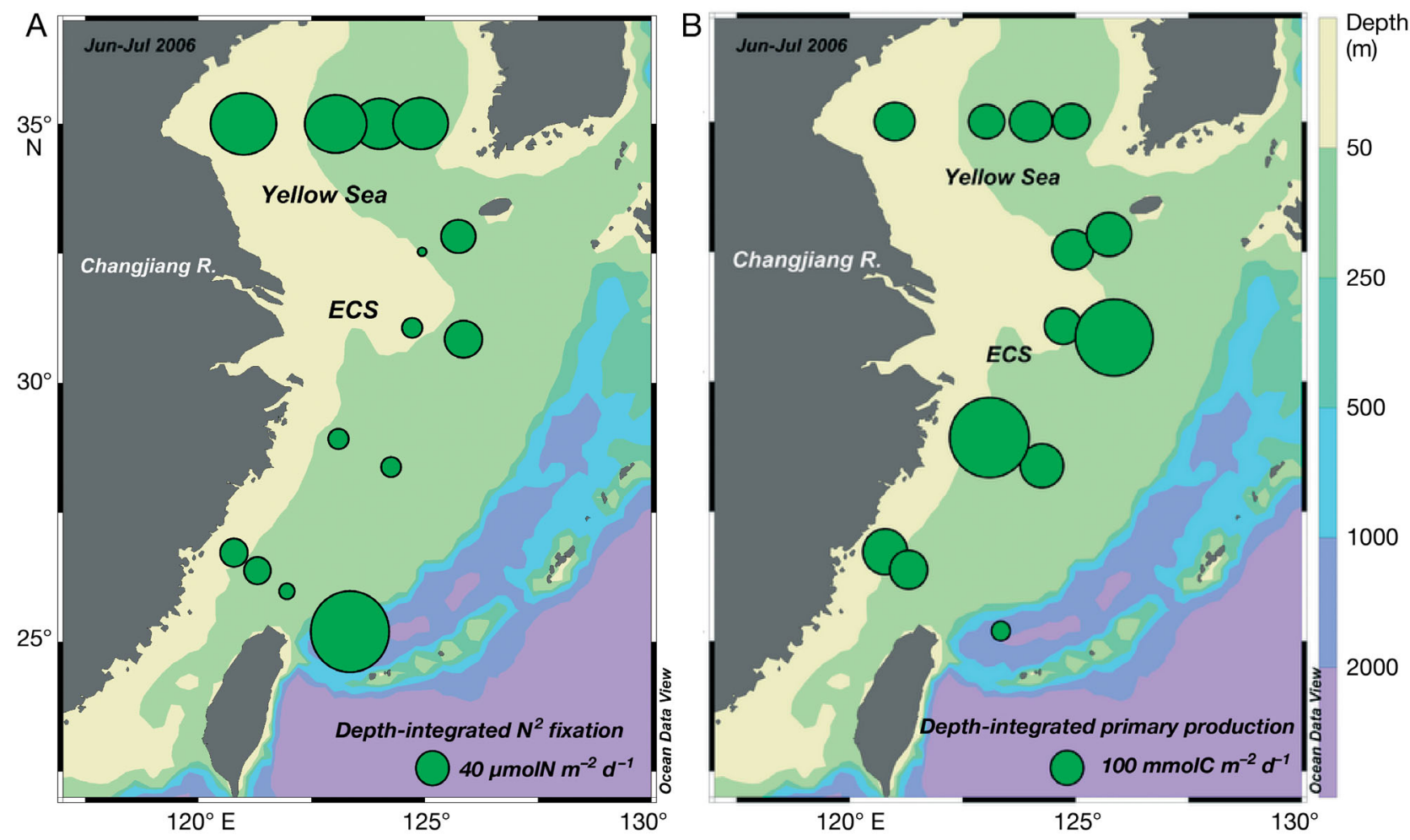

Fig. 5. Distributions of depth-integrated (A) $\mathrm{N}_{2}$ fixation and (B) primary production rates in the East China Sea (ECS) and the southern Yellow Sea. Circle area is proportional to rates as shown in the figure legend 


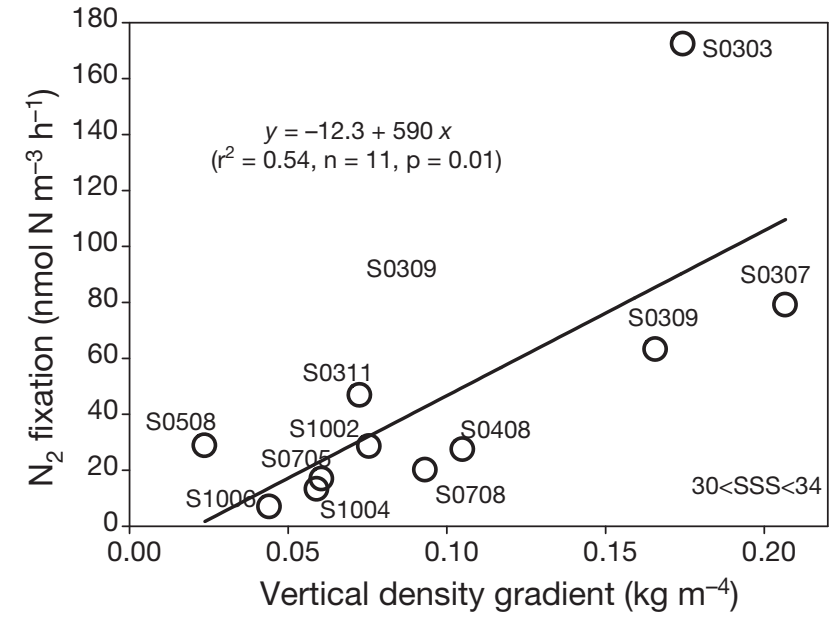

Fig. 6. Relationship between $\mathrm{N}_{2}$ fixation and vertical density $\left(\sigma_{\mathrm{t}}, \mathrm{kg} \mathrm{m}^{-3}\right)$ gradient in the upper water column $(<30 \mathrm{~m})$ of the mesohaline waters. The density gradient is the averaged density difference between the surface and $30 \mathrm{~m}$. SSS: sea surface salinity

Asaoka 1974, Chen 1982, Minagawa \& Wada 1986, Yang 1998, Chang et al. 2000, Bai et al. 2007). In the southern YS, water column stratification can be enhanced by the existence of the Yellow Sea Cold Water, a water mass below seasonal thermocline regarded as a remnant of winter cooling and mixing (Hu \& Wang 2004). Enhanced upper water column stratification may have weakened vertical nitrate injection and promoted $\mathrm{N}_{2}$ fixation, as observed in the North Pacific subtropical gyre and the central Atlantic (Karl et al. 1995, Sañudo-Wilhelmy et al. 2001). Meanwhile, the intrusion of the Kuroshio branch (Yellow Sea Warm Current, Mask et al. 1998) probably also aided $\mathrm{N}_{2}$ fixation, possibly by delivering oceanic diazotrophs.

\section{Biogeochemical importance of $\mathrm{N}_{2}$ fixation as a new $\mathrm{N}$ source to the ECS continental shelf in summer}

The contribution of $\mathrm{N}_{2}$ fixation to the $\mathrm{N}$ demand of primary production on the ECS continental shelf (0.01 to $0.16 \%, \mathrm{n}=8)$ and the southern YS (0.42 to $0.78 \%, \mathrm{n}=4$ ) are much lower than the Kuroshio $(4.6 \%)$, suggesting that $\mathrm{N}_{2}$ fixation plays a minor role in supporting phytoplankton $\mathrm{N}$ demand on the ECS continental shelf and the YS. Such values fell in the range of previous estimates $(0.2$ to $6 \%)$ for the Kuroshio-influenced water in the ECS (Marumo \& Asaoka 1974, Saino \& Hattori 1980, Chang et al. 2000), or the upstream Kuroshio $\left(20^{\circ} \mathrm{N}\right)$ and the adjacent South China Sea basin (Chen et al. 2008).
The major fixed $\mathrm{N}$ supplies to the ECS continental shelf include biological $\mathrm{N}_{2}$ fixation, Changjiang riverine input, upwelling of Kuroshio subsurface water, and atmospheric (dry and wet) deposition (Zhang 1996, Chen \& Wang 1999, Nakamura et al. 2005, Uno et al. 2007). However, no study has ever compared the relative importance of these sources, and such comparison will undoubtedly improve our basic understanding of the biogeochemical cycle in the ECS. Note that the Kuroshio area and the southern YS were not included in the evaluation here due to insufficiency of data.

If we adopt a daily $\mathrm{N}_{2}$ fixation rate of $21 \mu \mathrm{mol}$ $\mathrm{N} \mathrm{m}^{-2} \mathrm{~d}^{-1}(\mathrm{n}=9)$ measured on the ECS continental shelf and extrapolate to the whole ECS (area $=7.5$ $\left.\times 10^{5} \mathrm{~km}^{2}\right)$ continental shelf $(<200 \mathrm{~m}$, comprising $70 \%$ the whole ECS area), then $\mathrm{N}_{2}$ fixation may add $13 \mathrm{Gg}$ new $\mathrm{N}$ to the ECS continental shelf during summer. The Changjiang freshwater discharge in flood seasons (June to August) contributes to about $64 \%$ of the annual value of $925 \mathrm{~km}^{3}$ (Bureau of Hydrology, Changjiang Water Resources Commission; www.cjh.com.cn/). We adopt a riverine input of inorganic nitrogen (nitrate + ammonium) of $275 \mathrm{Gg} N$ in summer in combination with the concentration values in the freshwater discharge $\left(\left[\mathrm{NO}_{3}{ }^{-}\right]=32.9 \mu \mathrm{M}\right.$ and $\left[\mathrm{NH}_{4}{ }^{+}\right]=14.6 \mu \mathrm{M}$; Zhang 1996). Ammonium and nitrate are the most dominant species in the atmospheric deposition with an estimated total (nitrate + ammonium) flux of $430 \mathrm{Gg}$ $\mathrm{N}$ in the whole ECS (Nakamura et al. 2005). As model results show negligible seasonal variations for atmospheric inorganic nitrogen deposition (Uno et al. 2007), we adopt a summertime atmospheric deposition total $\mathrm{N}$ flux of $75 \mathrm{Gg}$ to the ECS continental shelf. Chen \& Wang (1999) estimated that an annual flux of $2072 \mathrm{Gg} \mathrm{N}$ nutrients is transported to the ECS as the Kuroshio subsurface waters upwell onto the ECS continental shelf, and a conservative value of $518 \mathrm{Gg} \mathrm{N}$ was adopted in our comparison. It is clear that $\mathrm{N}_{2}$ fixation does not contribute significantly to the sequestration of atmospheric $\mathrm{CO}_{2}$ on the ECS continental shelf (Tsunogai et al. 1999, Chen et al. 2004).

Acknowledgements. We are grateful to X. Bao, T. Li, and W. Men, who provided invaluable help during sampling. Thanks are due to X. Shi, C. Zhu, and C. Zhang for nutrient measurements. This work was supported by the National Natural Science Foundation of China (41125020), the National Key Basic Research Special Foundation Program of China (2005CB422305), and the Fujian Natural Science Foundation (2009J06026). 


\section{LITERATURE CITED}

Bai J, Jiang Y, Sun J, He Q (2007) The diurnal fluctuation of phytoplankton vertical distribution adjacent to the Yellow Sea cold water mass. Periodical Ocean Univ China 37:1013-1016

Beardsley RC, Limeburner R, Yu H, Cannon GA (1985) Discharge of the Changjiang into the East China Sea. Cont Shelf Res 4:57-76

> Chang J, Chiang KP, Gong GC (2000) Seasonal variation and cross-shelf distribution of the nitrogen-fixing cyanobacterium, Trichodesmium, in southern East China Sea. Cont Shelf Res 20:479-492

Chen CTA, Wang SL (1999) Carbon, alkalinity and nutrient budgets on the East China Sea continental shelf. J Geophys Res 104:20675-20686

> Chen C, Beardsley RC, Limeburner R, Kim K (1994) Comparison of winter and summer hydrographic observations in the Yellow and East China Seas and adjacent Kuroshio during 1986. Cont Shelf Res 14:909-929

> Chen CTA, Ruo R, Paid SC, Liu CT, Wong GTF (1995) Exchange of water masses between the East China Sea and the Kuroshio off northeastern Taiwan. Cont Shelf Res 15:19-39

> Chen CTA, Lin CM, Huang BT, Chang LF (1996) Stoichiometry of carbon, hydrogen, nitrogen, sulfur and oxygen in the particulate matter of the western North Pacific marginal seas. Mar Chem 54:179-190

Chen Y (1982) Analysis of a red tide event of Trichodesmium sp. in East China Sea in 1972. J Fish China 6:181-189

> Chen YLL, Lu HB, Shiah FK, Gong GC, Liu KK, Kanda J (1999) New production and f-ratio on the continental shelf of the East China Sea: Comparisons between nitrate inputs from the subsurface Kuroshio current and the Changjiang River. Estuar Coast Shelf Sci 48:59-75

> Chen YLL, Chen HY, Gong GC, Lin YH, Jan S, Takahashi M (2004) Phytoplankton production during a summer coastal upwelling in the East China Sea. Cont Shelf Res 24:1321-1338

> Chen YLL, Chen HY, Tuo SH, Ohki K (2008) Seasonal dynamics of new production from Trichodesmium $\mathrm{N}_{2}$ fixation and nitrate uptake in the upstream Kuroshio and South China Sea basin. Limnol Oceanogr 53:1705-1721

Church MJ, Mahaffey C, Letelier RM, Lukas R, Zehr JP, Karl DM (2009) Physical forcing of nitrogen fixation and diazotroph community structure in the North Pacific subtropical gyre. Global Biogeochem Cycles 23:GB2020

> Deutsch C, Sarmiento JL, Sigman DM, Gruber N, Dunne JP (2007) Spatial coupling of nitrogen inputs and losses in the ocean. Nature 445:163-167

Ding C (2009) The abundance, and the spatial and temporal distributions of cyanobacteria in the Yellow Sea, the East China Sea and the South China Sea. MSc thesis, China Ocean University, Qingdao

> Dong J, Zhang Y, Wang Y, Zhang S, Wang H (2008) Spatial and seasonal variations of cyanobacteria and their nitrogen fixation rates in Sanya Bay, South China Sea. Sci Mar 72:239-251

Gong GC, Chen YLL, Liu KK (1996) Chemical hydrography and chlorophyll a distribution in the East China Sea in summer: implications in nutrient dynamics. Cont Shelf Res 16:1561-1590

Gong GC, Wen YH, Wang BW, Liu GJ (2003) Seasonal variation of chlorophyll a concentration, primary production and environmental conditions in the subtropical East
China Sea. Deep-Sea Res II 50:1219-1236

> Grosse J, Bombar D, Doan HN, Nguyen LN, Voss M (2010) The Mekong River plume fuels nitrogen fixation and determines phytoplankton species distribution in the South China Sea during low-and high-discharge season. Limnol Oceanogr 55:1668-1680

Guan B (1994) Patterns and structures of the currents in Bohai, Huanghai and East China Seas. In: Di Z, Yuanbo L, ChengKui Z (eds) Oceanology of China Seas, Vol 1. Kluwer Academic Publishers, Dordrecht, p 17-26

Hama T, Shin KH, Handa N (1997) Spatial variability in the primary productivity in the East China Sea and its adjacent waters. J Oceanogr 53:41-51

Hansen HP, Koroleff F (1999) Determination of nutrients. In: Grasshoff K, Kremling K, Ehrhardt M (eds) Methods of seawater analysis, 3rd edn. Wiley-VCH, Weinheim, p 170-198

Hu D, Wang Q (2004) Interannual variability of the southern Yellow Sea Cold Water Mass. Chin J Oceanology Limnol 22:231-236

Ichikawa H, Beardsley RC (2002) The current system in the Yellow and East China Seas. J Oceanogr 58:77-92

> Karl DM, Letelier R, Hebel D, Tupas L, Dore J, Christian J, Winn C (1995) Ecosystem changes in the North Pacific subtropical gyre attributed to the 1991-92 El Niño. Nature 373:230-234

> Karl DM, Letelier R, Tupas L, Dore JE, Christian J, Hebel D (1997) The role of nitrogen fixation in biogeochemical cycling in the subtropical North Pacific Ocean. Nature 388:533-538

Karl DM, Michaels AF, Bergman B, Capone DG and others (2002) Dinitrogen fixation in the world's oceans. Biogeochemistry 57:47-98

Lee JS, Matsuno T (2007) Intrusion of Kuroshio water onto the continental shelf of the East China Sea. J Oceanogr 63:309-325

> Liu KK, Su MJ, Hsueh CR, Gong GC (1996) The nitrogen isotopic composition of nitrate in the Kuroshio Water northeast of Taiwan: evidence for nitrogen fixation as a source of isotopically light nitrate. Mar Chem 54:273-292

Liu KK, Peng TH, Shaw PT, Shiah FK (2003) Circulation and biogeochemical processes in the East China Sea and the vicinity of Taiwan: an overview and a brief synthesis. Deep-Sea Res II 50:1055-1064

Luo M, Lu J, Shen X, Chao M (2007) Horizontal distribution and dominant species of phytoplankton in the East China Sea. Acta Ecol Sin 27:5076-5085

Marumo R, Asaoka O (1974) Trichodesmium in the East China Sea. J Oceanogr 30:298-303

Marumo R, Nagasawa S (1976) Seasonal variation of the standing crop of a pelagic blue-green alga, Trichodesmium, in the Kuroshio water. Bull Plankton Soc Japan 23: $19-25$

Mask AC, O'Brien JJ, Preller R (1998) Wind-driven effects on the Yellow Sea Warm Current. J Geophys Res 103: 30713-30729

Mills MM, Ridame C, Davey M, LaRoche J (2004) Iron and phosphorus co-limit nitrogen fixation in the eastern tropical North Atlantic. Nature 429:292-294

> Minagawa M, Wada E (1986) Nitrogen isotope ratios of red tide organisms in the East China Sea: a characterization of biological nitrogen fixation. Mar Chem 19:245-249

> Montoya JP, Voss M, Kaehler P, Capone DG (1996) A simple, high precision tracer assay for dinitrogen fixation. Appl Environ Microbiol 62:986-993 
Montoya JP, Holl CM, Zehr JP, Hansen A, Villareal TA, Capone DG (2004) High rates of $\mathrm{N}_{2}$ fixation by unicellular diazotrophs in the oligotrophic Pacific Ocean. Nature 430:1027-1032

Nagasawa S, Marumo R (1967) Taxonomy and distribution of Trichodesmium (Cyanophyceae) in the Kuroshio Water. Inf Bull Planktol Jpn Commemoration number of Dr. Y. Matsue:139-144

Nakamura T, Matsumoto K, Uematsu M (2005) Chemical characteristics of aerosols transported from Asia to the East China Sea: an evaluation of anthropogenic combined nitrogen deposition in autumn. Atmos Environ 39: 1749-1758

Riemann L, Farnelid H, Steward GF (2010) Nitrogenase genes in non-cyanobacterial plankton: prevalence, diversity, and regulation in marine waters. Aquat Microb Ecol 61:235-247

Saino T (1977) Biological nitrogen fixation in the ocean with emphasis on the nitrogen fixation blue-green alga Trichodesmium and its significance in the nitrogen cycling in the low latitude sea areas. $\mathrm{PhD}$ thesis, University of Tokyo

Saino T, Hattori A (1980) Nitrogen fixation by Trichodesmium and its significance in nitrogen cycling in the Kuroshio area and adjacent waters. In: Takenouti AY (ed) The Kuroshio IV. Saikon Publishing, Tokyo, p 697-709

Sañudo-Wilhelmy SA, Kustka AB, Gobler CJ, Hutchins DA and others (2001) Phosphorus limitation of nitrogen fixation by Trichodesmium in the central Atlantic Ocean. Nature 411:66-69

Shiozaki T, Furuya K, Kodama T, Kitajima S, Takeda S, Takemura T, Kanda J (2010) New estimation of $\mathrm{N}_{2}$ fixation in the western and central Pacific Ocean and its marginal seas. Global Biogeochem Cycles 24:GB1015

Subramaniam A, Yager PL, Carpenter EJ, Mahaffey C and others (2008) Amazon River enhances diazotrophy and carbon sequestration in the tropical North Atlantic Ocean. Proc Natl Acad Sci USA 105:10460-10465

Suzuki T, Mori H, Ishizaka J, Katayama K (2007) Biomass and distribution of filamentous cyanobacteria, Trichodesmium spp., in spring in the East China Sea. Plankton

Editorial responsibility: Antonio Bode,

A Coruña, Spain
Benthos Res 2:175-183

$>$ Tian RC, Hu FX, Martin JM (1993) Summer nutrient fronts in the Changjiang (Yangtze River) estuary. Estuar Coast Shelf Sci 37:27-41

Tsunogai S, Watanabe S, Sato T (1999) Is there a 'continental shelf pump' for the absorption of atmospheric $\mathrm{CO}_{2}$ ? Tellus B Chem Phys Meterol 51:701-712

- Uno I, Uematsu M, Hara Y, He YJ and others (2007) Numerical study of the atmospheric input of anthropogenic total nitrate to the marginal seas in the western North Pacific region. Geophys Res Lett 34:L17817

> Voss M, Bombar D, Loick N, Dippner J (2006) Riverine influence on $\mathrm{N}_{2}$ fixation in the upwelling region of Vietnam, South China Sea. Geophys Res Lett 33:L07604

Wang J (2002) HAB alga nearby Changjiang Estuary. Mar Environ Sci 21:37-41

> Wang B, Wang X, Zhan R (2003) Nutrient conditions in the Yellow Sea and the East China Sea. Estuar Coast Shelf Sci 58:127-136

Weng XC, Zhang YK, Wang CM (1989) The variational characteristic of the Huanghai Sea (Yellow Sea) Cold Water Mass. J Ocean Univ Qingdao 19:119-131

> Wolfe DA, Schelske CL (1967) Liquid scintillation and Geiger counting efficiencies for carbon-14 incorporated by marine phytoplankton in productivity measurements. ICES J Mar Sci 31:31-37

> Wong GTF, Gong GC, Liu KK, Pai SC (1998) 'Excess nitrate' in the East China Sea. Estuar Coast Shelf Sci 46:411-418

Yan T, Zhou MJ, Zou JZ (2002) A national report on harmful algal blooms in China, Institute of Oceanology, Chinese Academy of Sciences, Qingdao

Yang Q (1998) Characteristics of Trichodesmium distribution in waters over continental shelves of the South Huanghai Sea and the East China Sea. Acta Oceanol Sin 20:93-100

Yuan Y, Guan B (2007) Overview of studies on some eddies in the China seas and their adjacent seas II. The East China Sea and the region east of the Ryukyu Islands. Acta Oceanol Sin 29:1-17

- Zhang J (1996) Nutrient elements in large Chinese estuaries. Cont Shelf Res 16:1023-1045

Zhou Z (1962) Red tide in Fujian. J Fujian Norm Coll 4:75-79

Submitted: June 10, 2011; Accepted: November 14, 2011

Proofs received from author(s): January 28, 2012 